\title{
PENERAPAN PEMBELAJARAN INTERAKTIF DENGAN CD PEMBELAJARAN PADA MATERI LINGKARAN UNTUK MENINGKATKAN AKTIVITAS BELAJAR MATEMATIKA SISWA DI SMP NEGERI 3 PANGKALAN KURAS
}

\author{
Darto \\ Dosen Tetap UIN Suska Riau Jurusan Pendidikan Matematika
}

\begin{abstract}
ABSTRAK
Pengembangan pembelajaran interaktif dengan menggunakan CD pembelajaran pada materi lingkaran dapat meningkatkan aktivitas belajar matematika siswa, hal ini disebabkan materi lingkaran yang abstrak dapat disajikan dalam bentuk kongkrit dengan menggunakan pembelajaran interaktif CD pembelajaran. Pembelajaran yang disajikan dengan kongkrit, sehingga siswa tidak bosan atau jemu dalam belajar matematika dan ini berimplikasi terhadap pembelajaran matematika. Selama ini anggapan siswa belajar matematika adalah sesuatu hal yang menakutkan apa lagi pada soal atau materi geometri dimana setiap materi begitu abstrak, sehingga siswa belajar matematika banyak mengalami kesulitan didalam memahami konsep-konsep matematika. Berdasarkan hasil analisis data dari perbandingan antara sebelum dan sesudah tindakan, maka dapat disimpulkan bahwa terjadi peningkatan aktivitas belajar matematika siswa terhadap pembelajaran matematika pada materi pokok lingkaran di kelas VIII SMP Negeri 3 Pangkalan Kuras Kabupaten Pelalawan melalui penerapan pembelajaran Interaktif dengan CD pembelajaran matematika.
\end{abstract}

Kata Kunci: Pembelajaran, Interaktif, matematika.

\section{PENDAHULUAN}

Mata pelajaran matematika memegang peranan penting di dalam dunia pendidikan, karena pelajaran matematika merupakan salah satu sarana yang digunakan untuk dapat membentuk siswa berfikir logis. Hal ini sesuai dengan fungsi matematika itu sendiri yang terdapat di dalam Kurikulum Tingkat Satuan Pendidikan (KTSP) yang menyatakan pelajaran matematika berfungsi mengembangkan kemampuan menghitung, mengukur, menurunkan dan menggunakan rumus matematika yang diperlukan dalam kehidupan sehari-hari melalui pengukuran, geometri, aljabar, dan trigonometri (Depdiknas, 2006).

Konsep pembelajaran matematika yang abstrak dapat disajikan dalam bentuk yang kongkrit dengan menggunakan gambar-gambar bergerak melalui animasi computer, sehingga pembelajaran matematika tersebut dapat dengan mudah dimengerti oleh siswa. Menurut Made (2009: 201) gambar-gambar multimedia melalui komputer dapat menyajikan konsep dalam suatu pembelajaran yang bersifat abstrak dan kompleks menjadi seuatu yang nyata, sederhana, sistematis dan sejelas mungkin, dengan demikian pembelajaran menggunakan komputer akan berlangsung secara tepat guna dan berdaya guna sehingga hasil belajar siswa dapat meningkat. Menurut Wina ( 2008: 218) multi media berbasis computer dapat pula dimanfaatkan sebagai sarana dalam melakukan simulasi untuk melatih keterampilan dan kompetensi tertentu, misalnya tampilan dalam bentuk animasi yang mungkin siswa dapat melakukan berbagai percobaan tanpa harus berada di laboratorium.

Suatu konsep pembelajaran dapat dikategorikan kompleks, jika sukar di simulasikan dengan hanya menggunakan gambar-gambar statis (tidak bergerak), membutuhkan keterampilan untuk dapat diaplikasikan, serta membutuhkan waktu yang cukup banyak untuk pelaksanaan pembelajaran.

Kesulitan belajar yang dihadapi oleh siswa, akibat kurang memahami konsep-konsep yang abstrak pada pembelajaran matematika serta daya tangkap siswa terhadap pembelajaran yang berbeda-beda. Guru lebih sering menerangkan konsep-konsep secara ringkas dengan menitikberatkan pada pembahasan soal-soal, hal ini membuat siswa kurang memahami materi pelajaran, jarang bertanya, jarang menjawab 
pertanyaan dari guru,, maupun mengemukakan pendapat selama proses pembelajaran.

Penulis menduga untuk meningkatkan hasil belajar serta aktivitas siswa selama proses pembelajaran matematika adalah dengan memanfaatkan lebih optimal multimedia pembelajaran, karena dengan menggunakan multimedia pembelajaran maka konsep-konsep yang abstrak dalam matematika dapat divisualisasikan lewat animasi computer berupa gambar-gambar bergerak. Hal ini sesuai dengan pendapat Baronn ( 1995 ; 3) bahwa keuntungan serta keefektifan dari suatu multimedia pembelajaran adalah meningkatkan hasil belajar domain kognitif, afektif, dan psikomotor, meningkatkan percaya diri, mempersingkat waktu pembelajaran, menghemat biaya, menciptakan active learning, mampu mengakomodasikan gaya belajar serta daya tangkap siswa yang berbeda-beda, serta dapat meningkatkan motivasi belajar siswa, mendorong siswa bereksplorasi dan meningkatkan rasa nyaman dalam belajar.

Konsep-konsep yang abstrak pada pembelajaran matematika, diduga dapat difahami oleh siswa, jika guru menggunakan multimedia pembelajaran interaktif, yang dapat membantu guru menyampaikan konsep-konsep yang abstrak menjadi kongkrit, melalui animasi berupa gambar-gambar bergerak sehingga diharapkan akan dapat meningkatkan aktifitas serta hasil belajar siswa. Oleh karena itu, penelitian pengembangan media pembelajaran berupa software pembelajaran interaktif perlu dilakukan, khususnya pada materi lingkaran. Software pembelajaran matematika yang telah ada diproduksi baik oleh pustekkom maupun institusi lainnya cukup baik hanya saja pemaparan isi terlalu ringkas dan kurang sesuai dengan kurikulum yang ada di sekolah sehingga guru masih perlu memberikan penjelasan dalam konsep-konsep yang disajikan.

Adapun materi pada pengembangan pembelajaran interaktif ini adalah materi lingkaran, yaitu KD.4.1 dan KD.4.2:

1. Menentukkan unsur-unsur dan bagian-bagian lingkaran

2. Menghitung keliling dan luas lingkaran
Materi pokok pada KD.4.1 dan KD 4.2. di jabarkan dalam software pembelajaran interaktif, adapun indikator-indikator nya adalah sebagai berikut:

1. Menyebutkan unsur-unsur dan bagian lingkaran, pusat lingkaran, jari-jari lingkaran, diameter lingkaran, busur, talibusur, juring dan tembereng

2. Menemukan nilai phi

3. Menentukkan rumus keliling dan luas lingkaran

4. Menghitung keliling dan luas lingkaran

Siswa akan sukar memahami konsep-konsep lingkaran jika guru mengajar dengan menggunakan metode ceramah, sehingga dalam pembelajaran belum menarik perhatian siswa. Dengan demikian jika guru merancang tanpa menggunakan multimedia interaktif, diduga siswa akan kesulitan memahami konsep-konsep abstrak yang dituntut pada KD.4.1 dan KD.4.2, sehingga indikator sulit tercapai. Indikator pembelajaran pada materi lingkaran diduga akan dapat tercapai dengan menggunakan software pembelajaran interaktif yang dapat menyajikan konsep-konsep yang abstrak menjadi kongkrit. Dengan demikian siswa dapat membangun pengetahuannya sendiri berdasarkan pengalamannya selama menggunakan software pembelajaran interaktif, waktu penyajian materi lebih singkat, memiliki fungsi pengulangan sehingga siswa dapat belajar bermakna dan menyenangkan.

\section{METODOLOGI PENELITIAN}

Penelitian ini merupakan Penelitian Tindakan Kelas (PTK). Subjek penelitian ini adalah siswa kelas VIII SMP Negeri 3 Kecamatan Pangkalan Kuras Kabupaten Pelalawan, sedangkan objek penelitian ini adalah aktivitas belajar matematika siswa terhadap pembelajaran matematika.

\section{HASIL DAN PEMBAHASAN Analisis Data}

Data yang akan dianalisis adalah data yang diperoleh dari hasil penelitian dan pengamatan yang telah dilakukan selama proses pembelajaran berlangsung, baik tanpa penerapan maupun 
setelah penerapan pembelajaran interaktif dengan menggunakan $\mathrm{CD}$ pembelajaran matematika.

Adapun teknik analisis data yang akan dilakukan adalah dengan analisis deskriptif yang membandingkan rata-rata antar sebelum dan setelah tindakan. Analisis deskriptif ini dilakukan kerena peneliti hanya ingin mendeskriptifkan data sampel dan tidak untuk membuat kesimpulan yang berlaku untuk semua populasi kerena dalam penelitian yang peneliti lakukan ini, populasi merupakan sampel dari penelitian. Selanjutnya analisis ini dilakukan dengan membandingkan nilai bobot rata-rata aktivitas belajar matematika siswa antara sebelum dan setelah tindakan. Berikut adalah tabel I tentang aktivitas belajar matematika siswa selama proses pembelajaran dengan tanpa penerapan dan setelah penerapan pembelajaran interaktif dengan $\mathrm{CD}$ pembelajaran matematika.

Tabel 1. Bobot Rata-rata Setiap Indikator Aktivitas Belajar Matematika Siswa Selama Proses Pembelajaran

\begin{tabular}{|c|c|c|c|c|c|c|c|c|}
\hline \multirow{3}{*}{$\begin{array}{l}\text { Indikator aktivitas belajar } \\
\text { matematika siswa }\end{array}$} & \multicolumn{8}{|c|}{ Bobot Rata-rata Selama Proses Pembelajaran } \\
\hline & \multicolumn{2}{|c|}{$\begin{array}{c}\text { Tanpa } \\
\text { Tindakan }\end{array}$} & \multicolumn{2}{|c|}{ Siklus I } & \multicolumn{2}{|c|}{ Siklus II } & \multicolumn{2}{|c|}{ Siklus III } \\
\hline & $\begin{array}{l}\text { Bobot } \\
\text { Rata2 }\end{array}$ & Ket & $\begin{array}{l}\text { Bobot } \\
\text { Rata2 }\end{array}$ & Ket & $\begin{array}{l}\text { Bobot } \\
\text { Rata2 }\end{array}$ & Ket & $\begin{array}{l}\text { Bobot } \\
\text { Rata2 }\end{array}$ & Ket \\
\hline $\begin{array}{l}\text { Siswa hadir dalam setiap } \\
\text { pembelajaran matematika }\end{array}$ & 2.46 & Sedang & 3.69 & $\begin{array}{l}\text { Sangat } \\
\text { Tinggi }\end{array}$ & 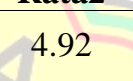 & $\begin{array}{l}\text { Sangat } \\
\text { Tinggi }\end{array}$ & 5 & $\begin{array}{l}\text { Sangat } \\
\text { Tinggi }\end{array}$ \\
\hline $\begin{array}{l}\text { Mengerjakan soal matematika } \\
\text { yang diberikan guru }\end{array}$ & 1.69 & Sedang & 2.62 & Sedang & 2. & lang & 4.77 & $\begin{array}{l}\text { Sangat } \\
\text { Tinggi }\end{array}$ \\
\hline $\begin{array}{l}\text { Siswa mampu menyelesaikan } \\
\text { masalah }\end{array}$ & 1.81 & Rendah & 2.38 & Rendah & 3.15 & Sedang & 4.23 & Tinggi \\
\hline $\begin{array}{l}\text { Mengikuti pelajaran } \\
\text { matematika dari awal hingga } \\
\text { akhir }\end{array}$ & 1.77 & Rendah & 2.15 & Rendah & 2.77 & ang & 3.5 & Tinggi \\
\hline $\begin{array}{l}\text { Siswa berdiskusi dengan teman } \\
\text { sekelompok }\end{array}$ & 1.85 & Rendah & 2.46 & Rendah & 2.92 & Sedang & 3.85 & $\begin{array}{l}\text { Sangat } \\
\text { Tinggi }\end{array}$ \\
\hline $\begin{array}{l}\text { Siswa dapat menyimpulkan } \\
\text { materi yang telah dipelajari }\end{array}$ & 1.77 & Rendah & 2.5 & Rendah & 2.85 & Sedang & 3.88 & $\begin{array}{l}\text { Sangat } \\
\text { Tinggi }\end{array}$ \\
\hline $\begin{array}{l}\text { Memusatkan perhatian dalam } \\
\text { pelajaran matematika }\end{array}$ & 1.69 & Rendah & 2.58 & Sedang & 3.08 & Sedang & 3.62 & tinggi \\
\hline $\begin{array}{l}\text { Siswa mempunyai catatan } \\
\text { setiap belajar matematika }\end{array}$ & 1.85 & Rendah & 2.58 & Sedang & 2.73 & Sedang & 3.56 & Tinggi \\
\hline $\begin{array}{l}\text { Jika siswa tidak mengerti siswa } \\
\text { bertanya }\end{array}$ & 1.85 & Rendah & 2.35 & Rendah & 2.96 & Sedang & 3.65 & Tinggi \\
\hline $\begin{array}{l}\text { Siswa berani mengemukakan } \\
\text { pendapat }\end{array}$ & 1. & $\mathrm{~h}$ & 2.35 & h & 2.96 & g & 3.85 & Tinggi \\
\hline Rata-rata & 1.83 & rendah & 2.57 & Sedang & 3.11 & Sedang & 3.99 & Tinggi \\
\hline
\end{tabular}

Berdasarkan tabel 1, dapat dilihat bahwasanya nilai rata-rata indikator aktivitas belajar matematika siswa mengalami peningkatan. Peningkatan terlihat jelas ketika sebelum dilakukan penerapan pembelajaran interaktif dengan $\mathrm{CD}$ pembelajaran matematika nilai rata-rata indikator aktivitas belajar matematika siswa adalah 1,83 (rendah), dan setelah dilakukan penerapan pembelajaran pembelajaran interaktif dengan $\mathrm{CD}$ pembelajaran matematika nilai bobot rata-rata aktivitas belajar matematika siswa meningkat menjadi 2,57 (sedang), 3.11 (sedang), dan 3.99 (tinggi).

Tabel 2. Bobot Rata-rata aktivitas Belajar Matematika Siswa Untuk Semua Indikator Selama Proses Pembelajaran

\begin{tabular}{|c|c|c|c|c|c|c|c|c|c|}
\hline \multirow{2}{*}{ NO } & \multirow{2}{*}{$\begin{array}{c}\text { Kode } \\
\text { Siswa }\end{array}$} & \multicolumn{2}{|c|}{ Tanpa Penerapan } & \multicolumn{6}{|c|}{ Melalui Penerapan } \\
\cline { 3 - 10 } & & Bbt & Ket & Bbt & Ket & Bbt & Ket & \multicolumn{2}{c|}{ Siklus III } \\
\hline 1 & A1 & $\mathbf{1 . 9}$ & Rendah & $\mathbf{2 . 1}$ & Rendah & $\mathbf{3 . 0}$ & Sedang & $\mathbf{3 . 5}$ & Sedang \\
\hline 2 & A2 & $\mathbf{2 . 2}$ & Rendah & $\mathbf{2 . 6}$ & Sedang & $\mathbf{3 . 2}$ & Sedang & $\mathbf{4 . 1}$ & Tinggi \\
\hline 3 & A3 & $\mathbf{2 . 1}$ & Rendah & $\mathbf{3 . 0}$ & Sedang & $\mathbf{3 . 2}$ & Sedang & $\mathbf{3 . 8}$ & Tinggi \\
\hline
\end{tabular}




\begin{tabular}{|c|c|c|c|c|c|c|c|c|c|}
\hline \multirow{3}{*}{ NO } & \multirow{3}{*}{$\begin{array}{c}\text { Kode } \\
\text { Siswa }\end{array}$} & \multirow{2}{*}{\multicolumn{2}{|c|}{ Tanpa Penerapan }} & \multicolumn{6}{|c|}{ Melalui Penerapan } \\
\hline & & & & \multicolumn{2}{|c|}{ Siklus I } & \multicolumn{2}{|c|}{ Siklus II } & \multicolumn{2}{|c|}{ Siklus III } \\
\hline & & Bbt & Ket & Bbt & Ket & Bbt & Ket & Bbt & Ket \\
\hline 4 & A4 & 1.7 & Rendah & 2.1 & Rendah & 2.9 & Sedang & 3.3 & Sedang \\
\hline 5 & A5 & 1.9 & Rendah & 2.5 & Rendah & 3.0 & Sedang & 3.6 & Tinggi \\
\hline 6 & A6 & 2 & Rendah & 2.5 & Rendah & 3.8 & Tinggi & 4.2 & Tinggi \\
\hline 7 & A7 & 1.6 & Rendah & 2.5 & Rendah & 3.0 & Sedang & 4.0 & Tinggi \\
\hline 8 & A8 & 2.1 & Rendah & 2.3 & Rendah & 3.2 & Sedang & 3.9 & Tinggi \\
\hline 9 & A9 & 1.8 & Rendah & 2.5 & Rendah & 3.1 & Sedang & 4.1 & Tinggi \\
\hline 10 & A10 & 1.7 & Rendah & 2.8 & Sedang & 3.0 & Sedang & 3.9 & Tinggi \\
\hline 11 & A11 & 1.7 & Rendah & 2.3 & Rendah & 3.1 & Rendah & 4.1 & Tinggi \\
\hline 12 & A12 & 2.1 & Rendah & 2.5 & Rendah & 2.8 & Sedang & 3.0 & Sedang \\
\hline 13 & A13 & 1.8 & Rendah & 2.8 & Sedang & 3.4 & Sedang & 4.1 & Tinggi \\
\hline 14 & A14 & 1.9 & Rendah & 2.6 & Sedang & 3.1 & Sedang & 4.0 & Tinggi \\
\hline 15 & A15 & 1.4 & Rendah & 2.4 & Rendah & 3.2 & Sedang & 3.8 & Tinggi \\
\hline 16 & A16 & 2.1 & Rendah & 2.9 & Sedang & 3.1 & Sedang & 3.8 & Tinggi \\
\hline 17 & A17 & 1.7 & Rendah & 2.6 & Sedang & 2.9 & Sedang & 3.4 & sedang \\
\hline 18 & A18 & 1.5 & S.Rendah & 2.8 & Sedang & 3.7 & Tinggi & 4.2 & Tinggi \\
\hline 19 & A19 & 1.6 & Rendah & 2.8 & Sedang & $\begin{array}{r}3.0 \\
\end{array}$ & Sedang & 3.8 & Tinggi \\
\hline 20 & A20 & 2.2 & Rendah & 3.0 & Sedang & 3.5 & Sedang & 4.0 & Tinggi \\
\hline 21 & A21 & 1.6 & Rendah & 2.3 & Rendah & 3.0 & Sedang & 3.5 & Sedang \\
\hline 22 & A22 & 1.5 & S.Rendah & 2.7 & Sedang & 3.0 & Sedang & 3.8 & Tinggi \\
\hline 23 & A23 & 1.7 & Rendah & 2.3 & Rendah & 3.3 & Sedang & 3.9 & Tinggi \\
\hline 24 & A24 & 2.1 & Sedang & 2.7 & Sedang & 3.2 & Sedang & 3.7 & Tinggi \\
\hline 25 & A25 & 2 & Rendah & 2.5 & Rendah & 3.3 & Sedang & 4.0 & Tinggi \\
\hline 26 & A26 & 1.9 & Rendah & 2.6 & Sedang & 3.1 & Sedang & 3.6 & Tinggi \\
\hline \multicolumn{2}{|c|}{ Total } & 47.8 & & 66.7 & & 81.1 & & 98.7 & \\
\hline \multicolumn{2}{|c|}{ Rata-rata } & 1.84 & Rendah & 2.56 & sedang & 3.11 & Sedang & 3.79 & Tinggi \\
\hline
\end{tabular}

Dari tabel 2, dapat dilihat bahwasanya terjadi peningkatan antara sebelum penerapan dengan siklus I, siklus II, dan siklus III. Setiap siswa mengalami peningkatan aktivitas belajar matematika siswa selama proses pembelajaran berlangsung. Sebagai contoh, misalnya siswa 26 mempunyai bobot rata-rata aktivitas belajar matematika siswa sebelum tindakan adalah 1.9 (rendah), setelah dilakukan tindakan melalui siklus I, siklus II, dan siklus III terlihat peningkatan menjadi 2.6 (sedang), 3.1 (sedang), dan 3.6 (tinggi). Hal tersebut menandakan adanya peningkatan aktivitas belajar matematika dengan menerapkan pembelajaran interaktif dengan $\mathrm{CD}$ pembelajaran matematika.

\section{Pembahasan hasil penelitian}

Berdasarkan hasil analisis yang dilakukan dapat disimpulkan bahwa bobot rata-rata aktivitas belajar matematika siswa mengalami peningkatan melalui penerapan pembelajaran interaktif CD pembelajaran matematika. Hal ini terbukti kerena bobot rata-rata aktivitas belajar matematika siswa terhadap pembelajaran matematika melalui penerapan pembelajaran interaktif $\mathrm{CD}$ pembelajaran matematika lebih tinggi jika dibandingkan dengan tanpa adanya penerapan pembelajaran interaktif dengan $C D$ pembelajaran matematika tersebut.

Dengan penerapan model pembelajaran ini, tingkat aktifitas belajar matematika siswa semakin meningkat kerena siswa benar-benar mengerti dengan apa yang dipelajarinya dimana materi yang abstrak dapat disajikan dengan kongkrit dengan menggunakan pembelajaran interaktif $\mathrm{CD}$ pembelajaran matematika, sehingga rasa ingin tahu yang ada dalam diri mereka semakin tinggi dan akhirnya proses kerja sama yang baik akan terjadi, semua siswa bekerja dan saling bertukar pikiran. Demikian halnya guru, guru akan semakin serius dan lebih bersungguh-sungguh dalam proses pembelajaran, hal ini dikerenakan semakin banyaknya siswa yang bertanya dan menanggapi dalam pembelajaran.

Pokok bahasan lingkaran merupakan salah satu pokok bahasan yang sangat cocok untuk diterapkan pada pembelajaran interaktif dengan 
CD pembelajaran matematika. Hal ini dikerenakan pokok bahasan geometri pada topik lingkaran tersebut banyak memberikan kesempatan bagi guru untuk mengaitkan dengan dunia luar dan sesuai dengan syarat pembelajaran mengunakan pembelajaran inetraktif dengan $\mathrm{CD}$ pembelajaran matematika, sehigga siswa benar-benar mengerti dengan apa yang dipelajarinya dan membuat mereka lebih tertarik untuk mendalami pelajaran matematika tersebut.

\section{KESIMPULAN}

Penerapan pembelajaran interaktif dengan CD pembelajaran matematika dapat meningkatkan aktivitas belajar matematika siswa pada materi pokok Lingkaran kelas VIII SMP Negeri 3 Pangkalan Kuras Kabupaten Pelalawan. Adapun peningkatan aktivitas belajar matematika siswa terhadap pelajaran matematika terjadi secara bertahap dari satu siklus ke siklus berikutnya yang dapat dilihat dari peningkatan indikator-indikator aktivitas belajar matematika.

\section{DAFTAR PUSTAKA}

Adi Wijaya. 2009. Model-Model Pembelajaran. Yogyakarta.

Arief S, Sadiman, dkk.1994. Media Pendidikan Pengertian, Pengembangan dan Pemanfaatannya. Jakarta: PT. Rajagrafindo Persada.

Dediknas. 2004. Materi Pelatihan Terintegrasi Matematika. Jakarta

Dediknas. 2008. Materi Pelatihan Kurikulum Tingkat Satuan Pendidikan (KTSP). Jakarta.

Depdiknas. 2006. Hakikat Kurikulum Matematika Pengembangan Silabus dan Rencana Pembelajaran. Jakarta.

Dewi Salma Prawiradilaga. 2009. PrinsipPrinsip Pembelajaran. Universitas Negeri Jakarta.

Diane Ronis. 2009. Problem Based Learning for Math and Science Integrating Inquiry and the Internet. United State of America.
J.Ronald Gentile, James P.Lalliey. 2003. Standars and Matery Learning. Thousand Oaks California.

Jack Ott. 1994. Alternative Assessment in the Mathematics Classroom. Newyork. Columbus.ohio. Mc Graw Hill California.

John A.Van De Walle. 2006. Matematika Sekolah Dasar dan Menengah Pengembangan Pengajaran Jilid 1. Jakarta: PT. Erlangga.

John A.Van De Walle. 2006. Matematika Sekolah Dasar dan Menengah Pengembangan Pengajaran Jilid 2. Jakarta: PT. Erlangga.

Linda Jansen Sheffield, dkk. 1996. Teaching and Learning Elementary and Middle School Mathematics. Newyork. Columbus.ohio. Mc Graw Hill California.

Lou Anne Johnson.2009. Pengajaran yang Kreatif dan Menarik.Jakarta: PT. Macanan Jaya Cemerlang.

Lukman Hakim. 2004. Teknik Jitu Menguasai Flash MX. Jakarta: PT. Elex Media Komputindo.

Mel Siberman. 2005. Aktive Learning 101 Strategi Pembelajaran Aktif. Jakarta: PT. Pustaka Insan Madani.

Mukhtar. 2007. Pendidikan Anak Bangsa. Jakarta: PT. Nimas Multima.

Muslimin Ibrahim. 2000. Pengajaran Berdasarkan Masalah. Pascasarjana UNESA Surabaya.

Nana Syaodih Sukmadinata.2005. Metode Penelitian Pendidikan. Bandung: PT. Remaja Rosdakarya.

Paul Ginnis. 2008. Trik dan Taktik Mengajar Strategi Meningkatkan Pencapaian Pengajaran di Kelas. Jakarta: PT. Mancanan Jaya Cemerlang.

Richard D. Van Scotter,dkk.1979. Foundation of Education Social Perspectives.University Of Colorado.

Rusdi Susilana. 2007. Media Pembelajaran. Bandung: CV. Wacana Prima.

Santi Maudiarti, dkk. 2009. Buku Kerja Prinsip Disain Pembelajaran. Universitas Negeri Jakarta. 
Suhermi, dkk. 2005. Strategi Pembelajaran Matematika. Riau: Unri Press.

Wahyudin . 2008. Pembelajaran dan ModelModel Pembelajaran Seri 1. Jakarta: CV. Ipa Abong.

2008. Pembelajaran dan Model-Model Pembelajaran Seri 2. Jakarta: CV. Ipa Abong.

2008. Pembelajaran dan Model-Model Pembelajaran Seri 3. Jakarta: CV. Ipa Abong.

2008. Pembelajaran dan Model-Model Pembelajaran Seri 4. Jakarta: CV. Ipa Abong.
2008. Pembelajaran dan Model-Model Pembelajaran Seri 5. Jakarta: CV. Ipa Abong.

Wahyudin Djumanta. 2007. Mari Memahami Konsep Matematika untuk Kelas VIII SMP. Jakarta: PT. Grafindo Media Pratama.

Wahyudin. dkk. 2003. Ensiklopedi Matematika untuk SLTP. Jakarta: CV. Tarity Samudra Berlian

Wilson Sumangunsong. 2006. Matematika untuk SMP Kelas VIII. Jakarta: PT. Erlangga.

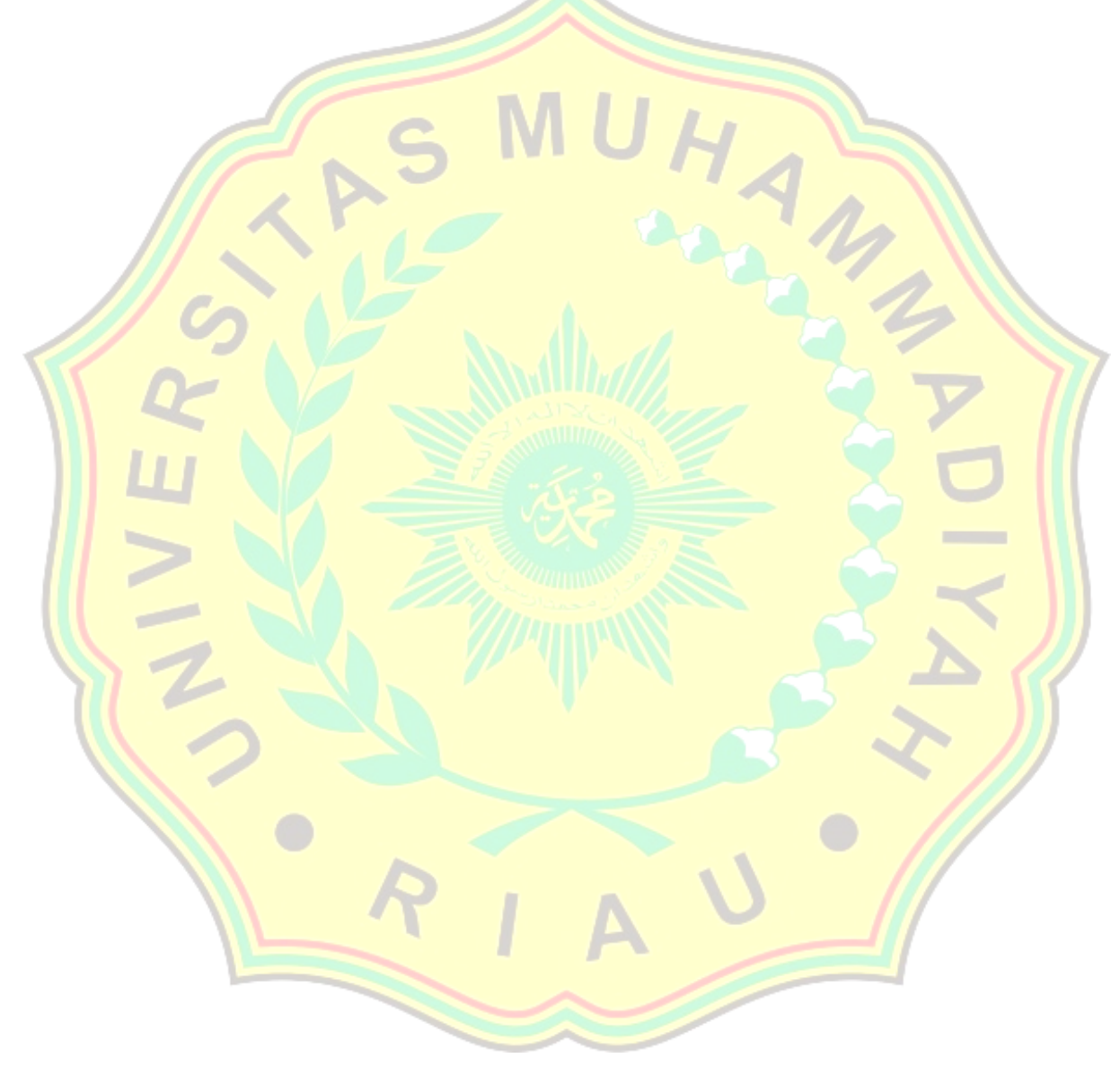

